\title{
What Factors Determine Use of Quality-related Marketing Research Information? An Empirical Investigation
}

Citation for published version (APA):

van Birgelen, M. J. H., de Ruyter, J. C., \& Wetzels, M. G. M. (2001). What Factors Determine Use of Quality-related Marketing Research Information? An Empirical Investigation. Total Quality Management, 12(4), 521-534. https://doi.org/10.1080/09544120123611

Document status and date:

Published: 01/01/2001

DOI:

10.1080/09544120123611

Document Version:

Publisher's PDF, also known as Version of record

Please check the document version of this publication:

- A submitted manuscript is the version of the article upon submission and before peer-review. There can be important differences between the submitted version and the official published version of record.

People interested in the research are advised to contact the author for the final version of the publication, or visit the DOI to the publisher's website.

- The final author version and the galley proof are versions of the publication after peer review.

- The final published version features the final layout of the paper including the volume, issue and page numbers.

Link to publication

\footnotetext{
General rights rights.

- You may freely distribute the URL identifying the publication in the public portal. please follow below link for the End User Agreement:

www.umlib.nl/taverne-license

Take down policy

If you believe that this document breaches copyright please contact us at:

repository@maastrichtuniversity.nl

providing details and we will investigate your claim.
}

Copyright and moral rights for the publications made accessible in the public portal are retained by the authors and/or other copyright owners and it is a condition of accessing publications that users recognise and abide by the legal requirements associated with these

- Users may download and print one copy of any publication from the public portal for the purpose of private study or research.

- You may not further distribute the material or use it for any profit-making activity or commercial gain

If the publication is distributed under the terms of Article $25 \mathrm{fa}$ of the Dutch Copyright Act, indicated by the "Taverne" license above, 


\title{
What factors determine use of quality-related marketing research information? An empirical investigation
}

\author{
Marcel van Birgelen, Ko de Ruyter \& Martin Wetzels \\ Maastricht University, Faculty of Economics and Business Administration, Department of \\ Marketing and Marketing Research, PO Box 616,6200 MD Maastricht, The Netherlands
}

\begin{abstract}
For effective total quality management (TQM), internal, process-related, as well as external, market-oriented, information is crucial. In particular, external marketing information seems to be very valuable since customers are the ultimate evaluators of the quality of an organization. In this paper, by adopting a services and relationship marketing perspective, we empirically study factors that influence the utilization of quality-related marketing research information by decisionmakers in organizations that strive to monitor and improve their quality levels. Our results show clearly that the use of quality-related information is most strongly influenced by the quality of informational contents. In addition, satisfaction with a specific quality-related research project functions as an important mediator between service quality of the project on the one hand and decision-maker trust in the provider and information use on the other hand. The results can be especially useful to marketing research agencies that strive to improve the quality of the service they deliver to organizations actively involved in the area of TQM.
\end{abstract}

\section{Introduction}

The importance of information for organizations has been widely acknowledged in managerial and academic literature. According to Naveh and Halevy (2000, p. 88), "In order to make better decisions, better information is needed". Driven by the recognition that knowledge management will be a critical success factor in today's business society (Lim et al., 1999), information seems to be crucial in the total quality management (TQM) arena as well. As stated by Savage (1996, p. 667), "The concept of total quality management (TQM) requires that all activities within an organisation, whether directly related to production or not, should be monitored with a view to improving their quality". In addition to intra-organizational information, however, external quality-related information will be equally important for effective TQM. Customers represent the ultimate entity in the business channel that needs to be satisfied by the provision of high-quality products and/or services. Effective use of external marketing information enables companies to become both more market- and

Correspondence: $\mathrm{M}$. van Birgelen, Maastricht University, Faculty of Economics and Business Administration, Department of Marketing and Marketing Research, PO Box 616, $6200 \mathrm{MD}$ Maastricht, The Netherlands. Tel: +31-43-3883839; Fax: +31-43-3884918; E-mail: m.vanbirgelen@mw.unimaas.nl 
customer-oriented and to improve their chances of succeeding in today's intensively competitive environment (Menon \& Varadarajan, 1992).

Given the importance of external marketing research information for the realization of quality improvements by organizations, it seems worthwhile to pay attention to factors influencing the utilization of information by organizational decision-makers. Despite recent efforts to clarify service quality of market research agencies (Donelly et al., 2000), the intelligence provider's role has remained unclear, especially in a TQM setting. In this paper, therefore, we aim to explain the use of quality-related marketing research intelligence from an intelligence provider's perspective. Since marketing research conducted for a client essentially is a service provided by a research agency, the simultaneous adoption of a services and relationship marketing perspective can be useful, as will become clear throughout the remainder of this paper. Underlying is the premise that, if the research service is provided adequately, relationships between intelligence providers and users are likely to develop. As a consequence, frequently studied factors such as service quality, satisfaction and trust represent important variables that need to be considered. A better understanding of how these variables affect the use of quality-related intelligence by decision-makers will enable research agencies to improve their service delivery process and become valued partners for organizations that strive to benefit from intelligence in their quest for quality improvements.

The structure of the paper is as follows. First, the general construct of intelligence use will be conceptualized by providing a brief review of the existing literature on this matter. Second, various antecedents of marketing research intelligence use will be identified and discussed. Subsequently, a conceptual model will be developed and operationalized by several research hypotheses. In this framework, use of quality-related marketing research information by organizational decision-makers and its related constructs will be incorporated. Finally, the results of an empirical study, aimed at testing our conceptual model, will be presented and several theoretical and managerial implications will be provided.

\section{Intelligence use: A conceptualization}

In the last two decades, the concept of marketing intelligence utilization has received considerable attention in the academic literature (Deshpandé \& Zaltman, 1982, 1984, 1985, 1987; Krishnan, 1989; Lee et al., 1987; Maltz \& Kohli, 1996; Menon \& Wilcox, 1994; Moorman et al., 1992, 1993; Raphael \& Parket, 1991). When reviewing this stream of literature, it becomes clear that the conceptualization of intelligence use has remained rather ambiguous. John and Martin (1984) consider intelligence use as the extent to which intelligence output is used directly for guiding behaviour and making decisions and, therefore, focus on a behaviourist mode of intelligence use. Maltz and Kohli (1996, p. 49), however, view market intelligence utilization as "the extent to which the receiver uses the intelligence disseminated by the sender to understand his or her work environment and make and implement decisions". Now, in addition to the behavioural dimension, a cognitive dimension that is directed at increasing knowledge is considered as well. Finally, Menon and Wilcox (1994) consider intelligence use to consist of three underlying dimensions: (a) action-oriented use for changing activities, practices, or policies on the basis of the findings and implications of a study; (b) knowledge-enhancing use that changes user knowledge and understanding of the issues under study; and (c) affective use by managers for the purpose of 'just feeling good' about decisions. This last conceptualization also incorporates an affective dimension of using research intelligence. Such shift in focus from a behaviourist, towards a cognitive and, ultimately, an affective dimension is a development that can already be seen in various fields of academic research. 
One of the most widely used conceptualizations of intelligence use makes a distinction between three different types of use: instrumental use; conceptual use; and symbolic use (Menon \& Varadarajan, 1992). The first type refers to the direct application of knowledge for solving a particular problem or making a particular decision (Deshpandé \& Zaltman, 1982). In other words, when intelligence is used instrumentally, a concrete problem exists and the solution depends on the information itself. Menon and Wilcox (1994) further differentiate instrumental use into congruous and incongruous use. Congruous use occurs when information is used consistent with the intent and implications of the study findings, e.g. changing a new product or service based on customer opinions assessed by conducting a pilot study. On the other hand, incongruous instrumental use is the intentionally distorted use of intelligence. This happens, for example, when information is pulled out of its context or twisted for political reasons and then used for determining company policies or strategies.

The second type of intelligence use, conceptual use, pertains to using information for general enlightenment rather than for any direct action in a given situation (Deshpandé \& Zaltman, 1982). Correspondingly, Menon and Wilcox (1994) view conceptual use as knowledge-enhancing use, either of the end product of a research project (the information itself) or the process of conducting research. This could, for example, occur because decisionmakers are interested in such a process or find it educational. Overall, conceptual or knowledge-enhancing use ultimately changes a decision-maker's understanding of specific issues being studied.

Finally, it is possible that information is distorted beyond its correct intent and used symbolically. This contrasts instrumental and conceptual use according to which findings are mainly being used consistently with the intent of a study (Menon \& Varadarajan, 1992). Symbolic use can occur in several ways. Research information can be misused by taking conclusions out of their context and disclosing only those that confirm an executive's predetermined positions. Another way is by oversimplifying findings and/or by consciously ignoring any accompanying caveats or assumptions that may weaken the findings (Weiss, 1977). Using findings to legitimize and sustain previously held dispositions, distorting findings to justify actions taken for other reasons, or using them selectively are also forms of symbolic use (Beyer \& Trice, 1982). Several factors are likely to affect the use of decisionmaking intelligence in its various manifestations. For developing a more fundamental understanding of utilization of quality-related research information, we shall now continue by paying further attention to factors possibly influencing intelligence use. The next section provides a brief overview of the current academic literature on this matter.

\section{Intelligence use: An overview of its determinants}

As mentioned before, when a research agency is conducting a marketing research project for one of its clients, in essence it is delivering a service. Recently, Donelly et al. (2000) investigated client perceptions of service quality of market research agencies using the wellknown SERVQUAL approach. Among other findings, they concluded that for research agencies the largest discrepancy lies in meeting client expectations of service reliability. However, in this study service reliability seemed to be a rather general concept, as it pertained to a wide range of items constituting the reliability dimension. Therefore, in order to substantiate this, we propose to follow the differentiation between technical and functional quality often made in services (Grönroos, 1990). Technical quality relates to the actual outcome of a service, which in this setting is the completed research project and the information provided. Functional quality refers to the very process by which a service is provided to customers, in other words, the way in which the outcome is achieved. For studying 
the use of quality-related research intelligence, a range of factors can be representative for technical and functional service quality dimensions. Several of these have already been included in previous studies on intelligence use.

Deshpandé and Zaltman (1982) related various factors to instrumental use of market research information, some of which are determinant for the technical service quality, e.g. certain characteristics of a research (report), whereas some relate more to functional service quality, e.g. the interaction between providers and users of information. With respect to the latter, interpersonal characteristics of the researcher, such as integrity and expertise, have been shown to determine the interaction between intelligence providers and users (Moorman et al., 1993). Among the main conclusions of Deshpandé and Zaltman (1982) was that perceived interaction, content quality, presentational quality, actionability and political acceptability of recommendations all significantly increased the instrumental utilization of research intelligence.

Furthermore, the level of user trust in the providers of research information was found to be ultimately influencing intelligence utilization (Maltz \& Kohli, 1996; Moorman \& Austin, 1995; Moorman et al., 1992). According to Moorman et al. (1993), whether firms merely possess information or actually use it is determined by the amount of user trust in information providers. Trust also had an effect on the perceived quality of user-provider interactions, researcher involvement and user commitment to the dyadic research relationship (Moorman et al., 1992). In turn, Moorman et al. (1993) concluded that trust is determined by several interpersonal characteristics, instcad being dependent on a researcher's individual characteristics. They concluded that trust between intelligence users and providers was determined by characteristics such as expertise, integrity, confidentiality, timeliness and sincerity of providers.

It is our premise that, in the long run, higher levels of trust can be expected to result in stronger intentions to continue the relationship with a provider of quality-related marketing research information (cf. Wetzels et al., 1998). On short notice, it seems important that clients are satisfied with the research service they are being provided with. If decision-makers are satisfied with both the process and outcome of a research project, it will become more likely that they will use the intelligence and develop higher trust in the intelligence provider. Departing from the previous discussion, a conceptual framework of quality-related marketing research information utilization will now be developed, based on a simultaneous services and relationship marketing perspective.

\section{A conceptual framework of quality-related information use}

We conceptualize quality-related research intelligence use as a combination of conceptual as well as instrumental use of information. Thus, the focus is on both the extent to which a decision-maker uses the information provided by a research agency to understand the work environment and to make and implement decisions with respect to (total) quality management. We base this conceptualization mainly on a common agreement between several studies that something is right with research intelligence that is used and something is wrong with information that is not used (Weiss \& Bucuvalas, 1980). In brief, our causal framework on the use of quality-related research information can be summarized as follows: quality-related information utilization is determined by the level of overall satisfaction with the process and outcome of a specific research project, as well as the level of user trust in the research agency providing the information. Furthermore, trust will be influenced by overall satisfaction with the research project, which is expected to depend on a set of four technical service quality variables (quality of contents, quality of form, actionability and acceptability of the 


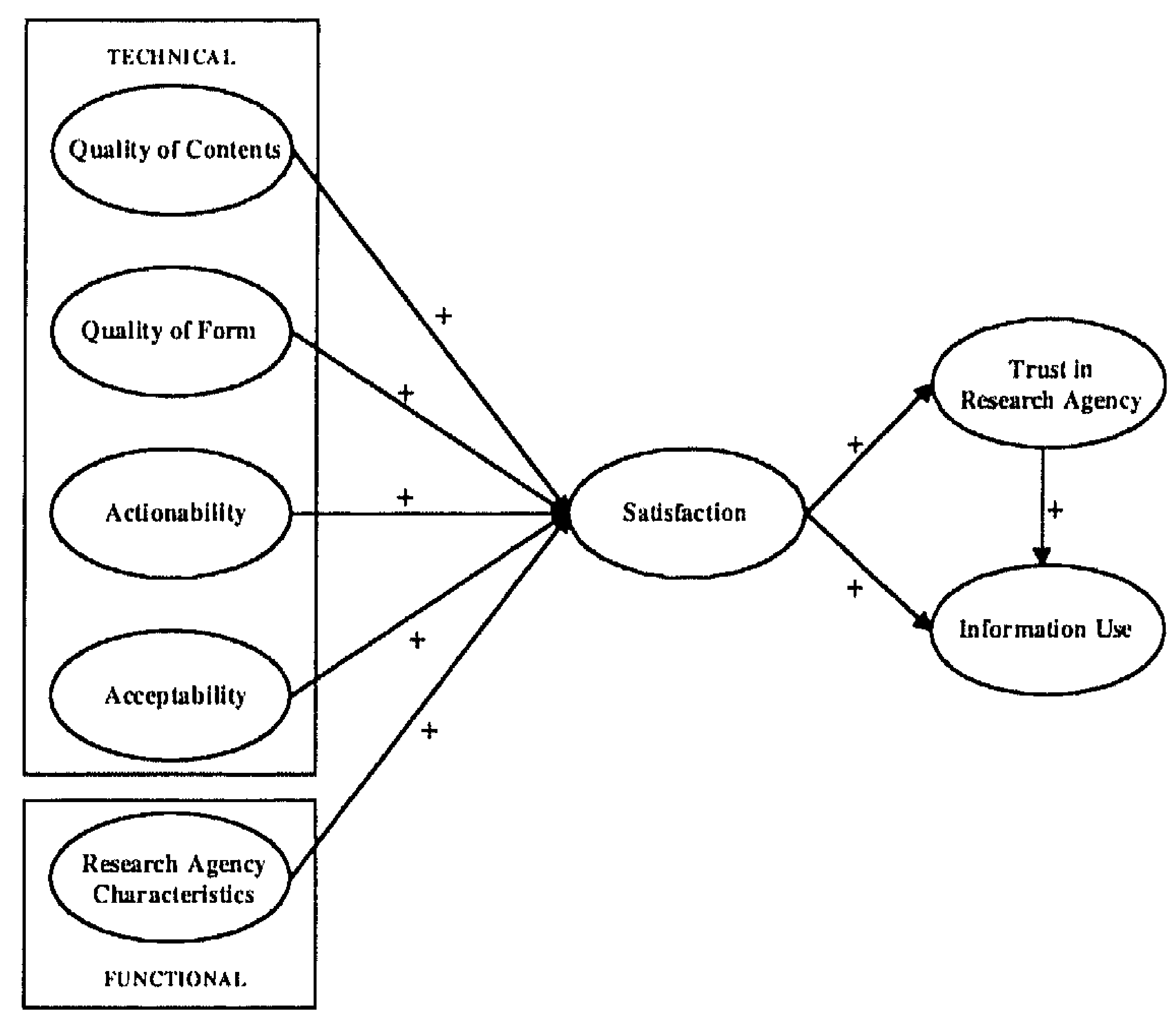

Figure 1. Conceptual framework of quality-related information use.

information) and one functional service quality variable (research agency interpersonal characteristics). Figure 1 visualizes our conceptual framework.

Higher levels of service quality are hypothesized to lead to higher overall client satisfaction. Oliver (1997) describes satisfaction as a consumer's cognitive and affective evaluation of the product/service that is being provided to him/her by a specific supplier. We consider overall satisfaction with the research project to be a central mediator in our framework, because of its proven importance in both the services and relationship marketing arena. The ultimate goal of all businesses is satisfaction of needs that motivate customers to do business with companies (Hanan \& Karp, 1989). For the establishment of long-term relationships, client satisfaction will be particularly important. Without satisfaction it is unlikely that clients will be motivated to continue the relationship with a provider of quality-related marketing research information in the long run. Furthermore, it has been shown that lasting relationships between business partners require a certain degree of trust between both parties (Wetzels et al., 1998). Therefore, we expect client trust in an intelligence provider to be dependent on overall satisfaction with the research project. Moorman et al. (1992, p. 315) define trust as "a willingness to rely on an exchange partner in whom one has confidence" and trust has been shown to lead to higher levels of market research information use (Moorman et al., 1992). Summarizing, overall satisfaction with individual research projects is expected to be important for providers of quality-related intelligence; on short notice by leading to increased information use and in the long run by building trust in the research agency. Consequently, the following relationships are hypothesized:

$H_{1}:$ There will be a positive relationship between satisfaction with the research project and quality-related information use.

$\mathrm{H}_{2}:$ There will be a positive relation between satisfaction with the research project and trust in the research agency. 
$H_{3}$ : There will be a positive relation between trust in the research agency and quality-related information use.

With respect to the technical quality of the research service, we hypothesize four variables to have an effect on overall satisfaction and, consequently, indirectly on decision-maker use of quality-related information. These variables are quality of contents, quality of form, actionability and acceptability of the information. The first variable, quality of contents, represcnts specific elements, which add to the perceived overall quality of a research project conducted by a marketing research agency. One can, for example, think of the research techniques that have been applied, the scientific foundations of the study, the data collection methods, whether or not the information is perceived to be worth the money paid for it, etc. (Rich, 1979). Perceived intelligence quality is likely to affect the level at which the information is acted upon (Menon \& Varadarajan, 1992). Quality of contents was found to be positively influencing the extent to which a decision-maker used the information (Deshpandé \& Zaltman, 1982, 1984). Consequently, we expect quality of contents to influence qualityrelated information use via overall satisfaction with the research project:

$H_{4}$ : There will be a positive relation between quality of contents and satisfaction with the research project.

The second technical service quality variable we refer to as the quality of form, either of the research report, its verbal presentation or a combination of both. Mostly, the (results of a) research project will be presented in a report to managers/decision-makers (Deshpandé \& Zaltman, 1982). It was found that higher levels of quality of form contribute to market research intelligence use (Deshpandé \& Zaltman, 1982, 1984). Consequently, we posit the following hypothesis:

$H_{5}:$ There will be a positive relation between quality of form and satisfaction with the research project.

Information is of value to decision-makers if it can be acted upon (Deshpandé \& Zaltman, 1982). Actionability of information is described as the level to which the information and corresponding recommendations are perceived to be practically implementable by decisionmakers and also has been shown to lead to higher levels of intelligence use (Deshpandé \& Zaltman, 1982, 1984):

\section{$H_{6}$ : There will be a positive relation between actionability of the quality-related information} and satisfaction with the research project.

Our final technical service quality variable is referred to as acceptability. Acceptability is the information's compatibility with an organization's main objectives. Kohli and Jaworski (1990) argue that a decision-makers' reaction of using information is likely to depend on how politically acceptable the information is for the organization as such and whether or not its status quo is being challenged. Political acceptability of market research information was shown to be positively influencing intelligence use (Deshpandé \& Zaltman, 1982, 1984). In the current study, it is hypothesized that acceptability of quality-related information will lead to overall satisfaction and thus indirectly to increased intelligence use:

$H_{7}$ : There will be a positive relation between acceptability of the quality-related information and satisfaction with the research project.

Functional service quality, representing the quality of the service delivery process, depends on a range of interpersonal characteristics of the research agency. Our expectation is that 
these characteristics will be indirectly influencing the utilization of quality-related intelligence by decision-makers in business organizations. Moorman et al. (1993, p. 82) provide the following definition of researcher interpersonal characteristics: "a broad set of researcher qualities that are demonstrated in user-researcher interactions". Expertise, integrity, flexibility and confidentiality are good examples of important researcher qualities. From past research, it can be concluded that interpersonal qualities and trust in the researcher are empirically related (Griffin, 1967; Moorman et al., 1993). As with the previous technical service quality variables, it is posited that overall satisfaction with the project functions as mediator in this relationship:

\section{$H_{8}:$ There will be a positive relation between research agency interpersonal characteristics and} satisfaction with the research project.

After having developed our theoretical framework on utilization of quality-related marketing research information, we shall now report on an empirical study that was conducted among users of such information in business organizations.

\section{An empirical study}

\section{Research design and data collection}

The population for our study consisted of managers at higher or middle-lower decisionmaking levels in consumer and business-to-business organizations. Respondents had to be regular users of quality-related marketing research information, provided by external, independent marketing research agencies. A list of approximately 400 members of the Dutch Association for Market Research and Information Management served as the sampling frame from which the actual sample was drawn. Using this list implied that the respondents all had expertise in dealing with research information. Each organization on the list was contacted by telephone and requested to participate in the study. Respondents who actually matched our target population and agreed upon participating were mailed questionnaire. This questionnaire had to be completed with respect to one specific marketing research project, recently conducted for (total) quality management purposes by an external marketing research agency.

In total, 162 questionnaires, accompanied by a covering letter and a postage-paid return envelope were mailed to decision-makers. Ultimately, 140 completed questionnaires were returned. However, after a critical review on the basis of control questions, included for the purpose of assessing job titles and whether or not respondents were regular users of marketing research information for making quality-related decisions, 20 respondents were excluded from our sample. Therefore, our final sample consisted of 120 respondents, representing a response rate of $74 \%$. Before performing the actual testing of our conceptual framework, we first had to check whether or not a non-response bias could threaten the quality of our data. This was done by performing a so-called time extrapolation test, as proposed by Armstrong and Overton (1977). The assumption of this test is that late respondents show more resemblance to non-respondents than early respondents. The results revealed that none of the variables assessed in the questionnaire showed a significant difference between early and late respondents, thereby providing evidence for the absence of non-response bias in our data.

\section{Questionnaire development}

The questionnaire was developed through an extensive review of the present academic literature on information utilization and by making use of the experience and knowledge of 
business practitioners. Before the actual data collection took place, our questionnaire was pre-tested by conducting in-depth interviews with managers who were regular users of marketing research information. The main goal of this pre-test was twofold: (1) to minimize the necessary length of the questionnaire; and (2) to identify and modify items that could make the survey instrument difficult to understand for decision-makers participating in our study. Indeed, from conducting the pre-test, several items were identified that needed to be adapted before including them in the final questionnaire.

The constructs incorporated in our theoretical framework were operationalized by using multiple items, formulated as statements. The items were measured on a seven-point Likerttype scale ranging from 1 (strongly disagree) to 7 (strongly agree). Quality of contents, quality of form, actionability and acceptability of the quality-related information (the four technical service quality variables) were operationalized by using scales developed by Deshpandé and Zaltman (1982). Seven items were used to measure quality of contents, quality of form was measured by four items, actionability by five items and acceptability also by five items. The research agency's interpersonal characteristics (representing functional service quality) were operationalized by five items of a scale developed by Moorman et al. (1993). Three items, developed specifically for the purpose of this study, measured overall satisfaction with both the process and outcome of the research project. Trust in the research agency was operationalized by six items of Moorman et al. (1992). Finally, quality-related information use was measured by seven items on the basis of a scale by Maltz and Kohli (1996). Some of the original items had to be modified for the specific setting of the current study. For the purpose of illustration, the items included in our questionnaire are presented in Table 1.

\section{Reliability analysis}

In order to assess the level of internal consistency of the scales we used to measure the constructs in our conceptual framework, several reliability analyses were performed. The Cronbach Alpha reliability scores are presented in Table 1. As can be seen in this table, all reliability scores closely approximate or exceed the threshold value of 0.70 as proposed by Nunnally and Bernstein (1994), providing evidence for sufficient reliability of the scales used.

\section{Hypotheses testing}

The theoretical framework and the corresponding hypotheses have been tested using structural equation modelling with LISREL 8 for obtaining maximum likelihood estimates of the path coefficients (Jöreskog \& Sörbom, 1993). After estimating the model, the various fit measures produced by LISREL 8 turned out to be good: $\chi_{(11)}^{2}=18.82 \quad(p=0.06)$, $G F I=0.97, A G F I=0.89, R M R=0.05, T L I=0.91, C F I=0.97$. All these fit measures closely approximate or exceed the recommended cut-off values (Bagozzi \& Yi, 1988; Jöreskog \& Sörbom, 1993). The hypothesized relationships were tested by inspecting the various path coefficients. Figure 2 renders the results of the final path analysis by presenting the significant relationships in our framework $(\alpha=0.05)$.

As can be concluded from Fig. 2, there is a significant positive relationship between the level of decision-maker overall satisfaction with the research process and outcome and utilization of the quality-related marketing research information. Therefore, hypothesis 1 is empirically supported by our data. In support of hypothesis 2 , a significant relationship was also found between decision-maker satisfaction and the level of trust in the research agency, an essential construct for establishing long-term relationships between the research agency and its clients. Hypothesis 3, however, is not supported by our study: no significant 
Table 1. Scale items and construct reliabilities

\begin{tabular}{|c|c|c|}
\hline Construct & Item ( $1=$ strongly disagree, $7=$ strongly agree) & $\alpha$ \\
\hline Quality of contents & $\begin{array}{l}\text { The research techniques wete applied appropriately } \\
\text { There were no contradictory statements of findings in the information provided } \\
\text { Frequent use of numbers and statistics was used as a smokescreen for otherwise useless } \\
\text { contents of the research } \\
\text { The way the information was gathered was appropriate } \\
\text { The information provided was not available elsewhere } \\
\text { The information provided was worth the money spent } \\
\text { The results of the research project could be used very well to solve current quality- } \\
\text { related problems within this organization }\end{array}$ & 0.69 \\
\hline Quality of form & $\begin{array}{l}\text { The language of the presentation was clear } \\
\text { There were too many tables/graphs/statistics in the presentation } \\
\text { The analysis of the data was more complex than necessary } \\
\text { There was enough interpretation and explanation of the findings in the presentation }\end{array}$ & 0.68 \\
\hline Actionability & $\begin{array}{l}\text { Besides statistical data the presentation also provided explicit recommendations for } \\
\text { action } \\
\text { The recommendations were easy to put into effect } \\
\text { All the recommendations could be implemented in practice } \\
\text { The information was on time for taking pending quality-related decisions } \\
\text { The information became available within the agreed time period }\end{array}$ & 0.84 \\
\hline Acceptability & $\begin{array}{l}\text { The recommendations seemed to be 'politically' acceptable to me } \\
\text { Some negative results were weakened } \\
\text { The recommendations reflected that the marketing research agency did not fully } \\
\text { understand what was 'politically' acceptable within our organization } \\
\text { The recommendations of this research project were not in line with the prevailing beliefs } \\
\text { at this organization } \\
\text { The recommendations of this research project fully corresponded with our wishes }\end{array}$ & 0.67 \\
\hline $\begin{array}{r}\text { Research agency } \\
\text { characteristics }\end{array}$ & $\begin{array}{l}\text { The research agency had a high level of expertise } \\
\text { The research agency seemed to have a great deal of integrity } \\
\text { The research agency seemed flexible enough in meeting our needs } \\
\text { The research agency carried out the research project effectively } \\
\text { The research agency can be expected to keep the information confidential }\end{array}$ & 0.82 \\
\hline Satisfaction & $\begin{array}{l}\text { I am very satisfied with the contents of the research project } \\
\text { I am very satisfied with the presentation of the research project } \\
\text { I am very satisfied with the marketing research agency conducting the research project }\end{array}$ & 0.89 \\
\hline $\begin{array}{l}\text { Trust in research } \\
\text { agency }\end{array}$ & $\begin{array}{l}\text { If } I \text {, or somebody else from this organization, could not be reached by the research } \\
\text { agency, I would be willing to let the agency make important research decisions } \\
\text { If } I \text {, or somebody else from this organization, could not monitor the research agency's } \\
\text { activities, I could trust the agency to do the job right } \\
\text { I trust the research agency to do things I cannot do myself } \\
\text { I trust the research agency to do things my organization cannot do } \\
\text { In general, I have little trust in the marketing research agency } \\
\text { Personally, I think the research findings are safe with the marketing research agency }\end{array}$ & 0.76 \\
\hline Information use & $\begin{array}{l}\text { The information of this research project helps this organization to formulate new quality } \\
\text { strategies } \\
\text { The information provided by the research agency will help our company to improve the } \\
\text { implementation of quality issues } \\
\text { The information of this research project helps to improve our organization's productivity } \\
\text { The information of this research project will hardly be used } \\
\text { The information of this research project has improved the organizational understanding } \\
\text { or the market-place } \\
\text { The information of this research project has improved the organizational understanding } \\
\text { of how customers perceive our quality } \\
\text { The information of this research project will lead this organization to undertake } \\
\text { concrete actions }\end{array}$ & 0.69 \\
\hline
\end{tabular}




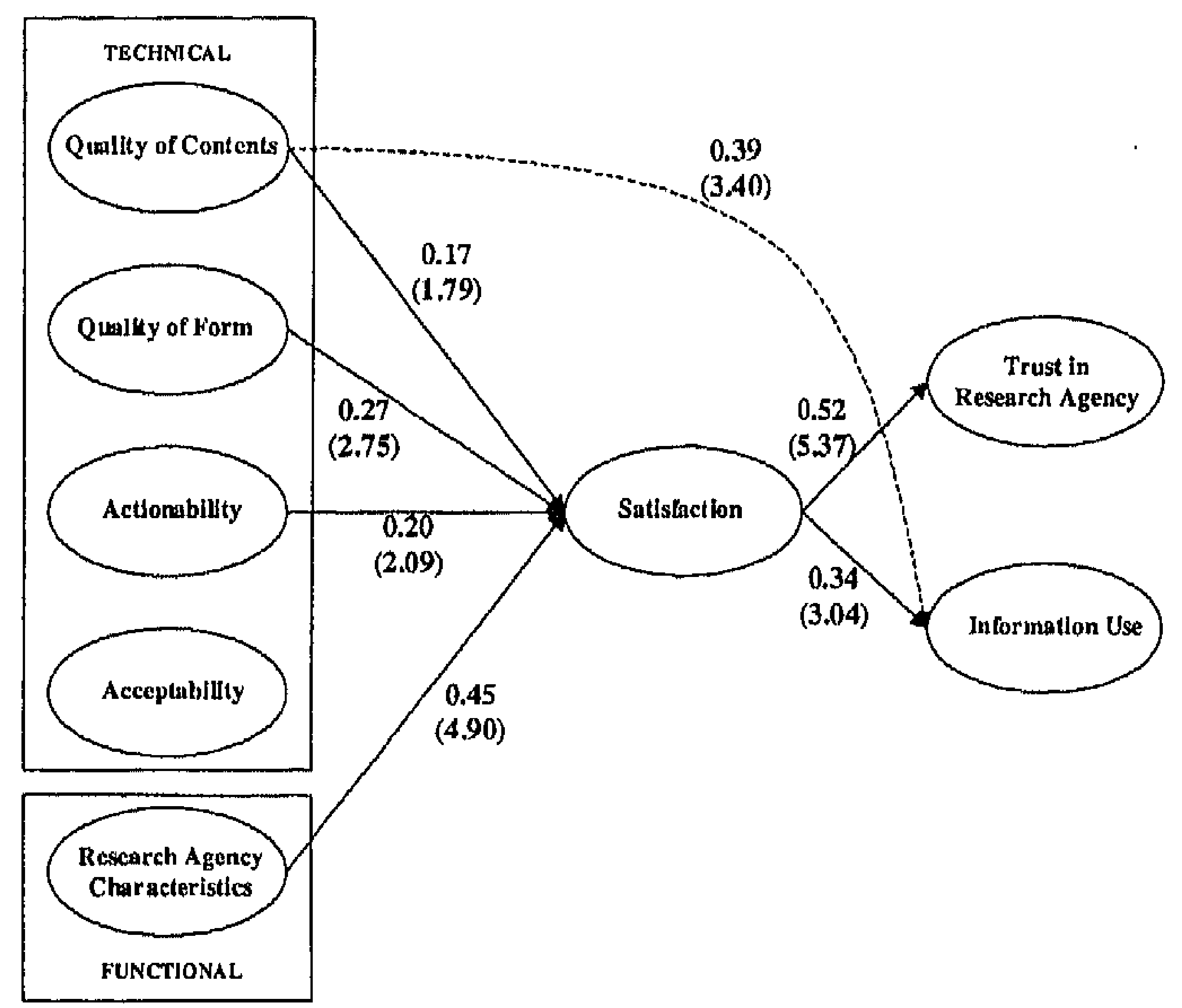

Figure 2. Causal model of quality-related information use. Only significant standardized path coefficients are shown $(\alpha=0.05)$. $\mathrm{t}$-values between parentheses.

relationship was found between the level of trust in the research agency and quality-related information use.

With respect to the technical or outcome-related service quality, it was found that three factors significantly influence overall satisfaction. Hypotheses 4 and 5 failed to be rejected: indeed, taking care of both higher levels of content quality as well as the way in which the project and the information are presented to decision-makers contributes significantly to higher overall satisfaction with the research project. Furthermore, in accordance with hypothesis 6 , when clients feel that the quality-related information and recommendations can be implemented in practice, this is also likely to result in higher overall satisfaction. Only the level to which the information seems to be acceptable to decision-makers and in line with prevailing beliefs at the client organization turns out not to result in a significant increase in satisfaction with the research project. Therefore, hypothesis 7 is rejected.

In addition to technical service quality, functional or process-related service quality is found to be relevant when conducting a quality-related research project. As proposed by hypothesis 8 , better interpersonal characteristics of the research agency will significantly increase the overall satisfaction of decision-makers with the research project. Finally, by inspecting the modification indices provided by LISREL 8 , one additional relationship was found that originally was not hypothesized. Quality of contents of a research project turns out to have a direct positive effect on the level to which the quality-related information is going to be used by decision-makers. Apparently, in this case the role of satisfaction with the project is of marginal importance.

\section{Conclusion}

Discussion

The objective of this paper was to develop and test a theoretical framework on the use of quality-related marketing research information by decision-makers in business organizations. 
The results remarkably suggest that the use of such information is most strongly related to quality of the contents of a research project and its resulting information. This relationship was found to be direct, thereby supporting previous findings of Deshpandé and Zaltman (1982, 1984). It seems that conducting research projects with high content quality is of crucial importance to research agencies for having their quality-related information used by clients, either for taking concrete actions with respect to TQM (instrumental use) or for developing a better understanding of the current situation (conceptual use). When decisionmakers develop a client perception that the information is of high quality and reliable, satisfaction with factors such as how the information is presented or certain characteristics of the research agency are important to a lesser extent. However, this does not imply that overall satisfaction with a quality-related marketing research project as such is of no relevance. On the contrary, overall client satisfaction will also contribute to increased utilization of quality-related information. Given the additional positive effect of quality of contents on overall satisfaction, a focus on this particular type of technical service quality seems to be of the utmost importance for research agencies.

In addition, to increase quality-related information use, overall satisfaction will also result in higher levels of client trust in the research agency, a factor which is important for building lasting relationships between two partners. Thus, satisfying clients will yield both long-term as well as short-term rewards. On short notice, the information will be used by decision-makers; in the long run, decision-makers are likely to develop more trust in the information provider. This is especially important since research has shown that higher levels of trust in a partner will increase a client's intention to continue its relationship with that partner (Wetzels et al., 1998). The fact that no significant relationship was found between trust and quality-related information use indicates that both factors are independent consequences of satisfaction, the former relating to long-term relationships, the latter to shortterm use of the information provided. Because of the apparent relevance of decision-maker satisfaction, it is important to know what factors influence it. As can be concluded from this study, adopting a services marketing perspective in this matter seems to be useful. Functional (process-related) service quality, represented by the research agency's interpersonal characteristics, was found to be the strongest determinant of overall client satisfaction. Relevant interpersonal characteristics in this setting are agency expertise, integrity, flexibility and confidentiality. In addition to process quality, providing technical (outcome-related) quality should not be lost from sight. As discussed previously, taking care of quality of the contents of a research project is crucial. Of the technical service quality factors, quality of form or the way in which the information and recommendations are presented to decision-makers has the strongest effect on overall satisfaction. This can be achieved, for example, by using clear language and presenting not too many and too complex statistics and analyses. Providing information with which decision-makers can do something in practice will also increase client overall satisfaction. Only quality-related information that appears to be actionable is useful to decision-makers in practice. Finally, acceptability of the information is of limited importance for establishing satisfaction and thus information use. This might be explained by the notion that decision-makers develop the impression that results and recommendations cannot be correct when they too closely match the prevailing beliefs within an organization. In this way, results that are too rosy could lead to the research agency losing credibility.

\section{Theoretical implications}

Part of the strength of a study is derived from recognizing its limitations. In doing so, issues that deserve further research efforts can be identified. First, the operationalization of the 
various constructs in our framework could be improved further. Indeed, several reliability coefficients are already sufficiently high. However, further development of the measures is likely to result in higher reliability levels and consequently better measurement of the constructs under study. The second issue relates to the apparent importance of quality of the contents of a research project. In practice, it turns out that it is often quite difficult for decision-makers to evaluate adequately this particular type of technical service quality, due to its high level of knowledge specificity. The solution might be found in more objective measures of content quality. One can, for example, think of additional questions on whether or not non-response justifications in a particular quality-related research project were given by the agency, whether or not more sophisticated analysis techniques have been applied, etc.

Third, the theoretical framework as tested in this study could be extended by including additional variables. The level of surprise of decision-makers about the research results might be an interesting construct in this respect. By including this variable, it can be determined whether or not the results are in accordance with client expectations and how this influences overall satisfaction with the project and thus ultimately use of quality-related information. In addition, in this study no explicit distinction was made between the various types of intelligence use, as discussed previously. The focus was on a combination of both instrumental and conceptual use of research information. Future research could differentiate further between the types of use and facilitate a more thorough understanding of the various objectives of using information and their specific antecedents.

A future differentiation could also be made between various types of information being provided by a research agency. The information focused on in the present study is mainly characterized as primary information, that is, information collected specifically for the client's decision-making situation with respect to (total) quality management. If the focus had been on the use of secondary information, different empirical results might have been found, since then the research agency would have had little direct control over the reliability of information provided by a third party and, consequently, over the quality of the contents of a research project. This variable then might play a different role in this specific setting. Another direction for future research is the distinction between quality-related information use in consumer versus business-to-business organizations. Results of previous research suggest that there are certain inconsistencies between these settings with respect to determinants of intelligence use (Deshpandé \& Zaltman, 1987). Separate follow-up studies are likely to yield more differentiated conclusions. The final limitation relates to the static perspective that was taken in this study. The data used to test our theoretical framework were collected at one specific point in time. Future research should be conducted longitudinally in order to determine the dynamics in the empirical relationships between the constructs over time and to assess cause-and-effect relationships more thoroughly.

\section{Managerial implications}

As could already be concluded from our previous discussion, the results of this study have several managerial implications for research agencies, providing clients with quality-related marketing research information. Striving for research projects with high levels of quality of contents should be a prominent goal for such agencies. Quality of contents is not only likely to result in higher overall client satisfaction, but also will result directly in higher utilization. of the information for (total) quality-related decision-making purposes. Quality of contents can, for example, be achieved by ensuring thorough application of (scientific) research techniques, data collection methods, giving the client a feeling of value for money, and not placing too much emphasis on numbers and statistics. In the long run, satisfying clients will 
be essential for the continuing existence of information providers. Satisfaction builds client trust in the research agency, which is of importance for a client's intention to continue its relationship with the provider.

By delivering functional as well as technical service quality, clients will become more satisfied and ultimately are going to use the quality-related information. Functional quality relates to the service delivery process of conducting a research project, which, to a great extent, is under the provider's own control. Most important in this respect are interpersonal characteristics of the agency, such as high levels of expertise, integrity, flexibility and confidentiality. In addition to the way in which the service is provided, the outcome of this process, referred to as technical service quality, also contributes significantly to overall satisfaction. One can think of clear and comprehensive ways of presenting the research results, with not too many graphs, tables and statistics and too complex analyses. Furthermore, providing information with high content quality, resulting in actionable recommendations that can be readily implemented in practice is important as well. This requires the agency to develop a deeper understanding of a client's specific decision-making situation. Taking care of these managerial implications will make the decision-makers see qualityrelated information providers as useful and trustworthy partners, who can add value to business organizations trying to exploit the benefits of TQM.

\section{References}

ARMSTRONG, J.S. \& OVERTON, T.S. (1977) Estimating nonresponse bias in mail surveys, fournal of Marketing Research, 14, pp. 369-402.

BAGOZZI, R.P. \& YI, Y. (1988) On the evaluation of structural equation models, foturnal of the Academy of Marketing Science, 16, pp. 74-94.

BEYER, J.M. \& TRICE, H.M. (1982) The utilization process: a conceptual framework and synthesis of empirical findings, Administrative Science Quarterly, 27, pp. 591-622.

DeshrandE, R. \& ZALTMAN, G. (1982) Factors affecting the use of market research information: a path analysis, fournal of Marketing Research, 19, pp. 14-31.

DESHPANDE, R. \& ZALTMAN, G. (1984) A comparison of factors affecting researcher and manager perceptions of market research use, fournal of Marketing Research, 21, pp. 32-38.

DESHPANDÉ, R. \& ZALTMAN, G. (1985) The use of market research in industrial organizations. In: R. SPEKMAN \& D. WILson (Eds) A Strategic Approach to Business Marketing (Chicago, American Marketing Association), pp. 58-66.

DESHPANDE, R. \& ZALTMAN, G. (1987) A comparison of factors affecting use of marketing information in consumer and industrial firms, fournal of Marketing Research, 24, pp. 114-118.

DONNELLY, M., VAN'THulL, S. \& WILL, V. (2000) Assessing the quality of service provided by market research agencies, Total Quality Management, 11, pp. 490-500.

GRIFFIN, K. (1967) The contribution of studies of source credibility to a theory of interpersonal trust in the communication process, Psychological Bulletin, 68, pp. 104-120.

Grönroos, C. (1990) Service Management and Marketing: Managing Moments of Truth in Service Competition (Massachusetts \& Toronto, Lexington Books).

Hanan, M. \& KARP, P. (1989) Customer Satisfaction (New York, Amacom American Management Association).

JOHN, G. \& MARTIN, J. (1984) Effects of organizational structure of marketing planning on credibility and utilization of plan output, fournal of Marketing Research, 21, pp. 170-183.

Jöreskog, K.G. \& SÖRBOM, D. (1993) LISREL 8: Structural Equation Modeling with the SIMPLIS Command Language (Hillsdale, Scientific Software International/Chicago, Lawrence Erlbaum Associates).

KoHli, A. \& JAwORskl, B.J. (1990) Market Orientation: The Construct, Research Propositions, and Managerial Implications, Report No. 90-113, Marketing Science Institute, Cambridge, MA, November.

KRISHNAN, S. (Ed.) (1989) Making More Effective Use of Market Information: A Conference Summary, Report No. 89-113, Marketing Science Institute, Cambridge, MA, September.

LEE, H., AcITO, F. \& DAY, R.L. (1987) Evaluation and use of marketing research by decision makers: a behavioral simulation, fournal of Marketing Research, 24, pp. 187-196.

LIM, K.K., AHMED, P.K. \& ZAIRI, M. (1999) Managing for quality through knowledge management, Total Quality Management, 10, pp. 615-621. 
MALTZ, E. \& KOHLI, A.K. (1996) Market intelligence dissemination across functional boundaries, fournal of Marketing Research, 33, pp. 47-61.

MENON, A. \& VARADARAJAN, R. (1992) A model of marketing knowledge use within firms, fournal of Marketing, 56, pp. 53-71.

Menon, A. \& Wilcox, J. (1994) USER: A Scale to Measure Use of Market Research, Report No. 94-108, Marketing Science Institute, Cambridge, MA, May, pp. 1-20.

Moorman, CH. \& Austin, J. (1995) The Paradox of Low Quality and High Use: How Research Trust Impacts Market Research Outcomes, Report No. 95-116, Marketing Science Institute, Cambridge, MA.

Moorman, CH., DeshrandÉ, R. \& Zaltman, G. (1993) Factors affecting trust in market research relationships, Fournal of Markating, 57, pp. 81-101.

Moorman, CH., Zaltman, G. \& Deshrandé, R. (1992) Relationships between providers and users of market research: the dynamics of trust within and between organizations, fournal of Marketing Research, 29, pp. 314-328.

NaveH, E. \& Halevy, A. (2000) A hierarchical framework for a quality information system, Total Quality Managemem, 11, pp. 87-111.

NunNally, J.C. \& Bernstein, I.H. (1994) Psychometric Theory (New York, McGraw-Hill),

Oliver, RL. (1997) Satisfaction: A Behavioral Perspective on the Consumer (New York, McGraw-Hill).

RAPHAEL, J. \& PARKET, R. (1991) The need for market research in executive decision making, fournal of Business \& Industrial Marketing, 6, pp. 15-21.

$\mathrm{Rich}_{2}$ R. (1979) The Power of Social Science Information and Public Policy Making (San Francisco, Jossey-Bass).

SAVAGE, B.M. (1996) Managing quality data, Tital Quality Management, 7, pp. 667-674.

WEISs, C.H. (1977) Using Social Research in Public Policy Making (Lexington, MA, D.C. Health \& Company).

Weiss, C.H. \& Bucuvalas, M.J. (1980) Social Science Research and Decision-making (New York, Columbia University Press).

Wetzels, M., De RuYter, K. \& VAN Birgelen, M. (1998) Marketing service relationships: the role of commitment, fournal of Business E Indtstrial Marketing, 13, pp. 406-423. 